\title{
Effects of amino acids and casein on copper uptake from soil by chicory (Cichorium intybus L. cv. Grasslands Puna)
}

\author{
M.T. LIAO, M.J. HEDLEY, D.J. WOOLLEY, R.R. BROOKS and M.A. NICHOLS \\ Institute of Natural Resources, College of Science, Massey University, Palmerston North
}

\begin{abstract}
A greenhouse pot trial was conducted to investigate the effect of addition of amino acids and casein to $\mathrm{Cu}$ fertilisers on $\mathrm{Cu}$ uptake by chicory (Cichorium intybus L. cv. Grasslands Puna) plants. Irrespective of the forms and rates of $\mathrm{Cu}$ applied, the addition of amino acids and casein had no significant effects on chicory shoot dry weight. $\mathrm{CuSO}_{4}$ resulted in significantly higher shoot $\mathrm{Cu}$ accumulation than $\mathrm{Cu}(\mathrm{OH})_{2}$. Addition of histidine (His), methionine (Met), aspartic acid (Asp) and casein to $\mathrm{Cu}(\mathrm{OH})_{2}$ significantly increased Cu uptake at $100 \mathrm{mg} \mathrm{Cu} / \mathrm{kg}$ soil treatments. Total accumulation of $\mathrm{Cu}$ from casein $+\mathrm{Cu}$ was significantly higher than from Met $+\mathrm{Cu}$ and $\mathrm{Cu}$ alone at $50 \mathrm{mg} \mathrm{Cu}$ as $\mathrm{CuSO}_{4} / \mathrm{kg}$ soil treatments. At the rate of $100 \mathrm{mg} \mathrm{Cu}$ as $\mathrm{CuSO}_{4} / \mathrm{kg}$ soil, the addition of His and casein resulted in significantly higher total shoot $\mathrm{Cu}$ accumulation than the addition of Met, Asp and $\mathrm{CuSO}_{4}$ alone. When $\mathrm{Cu}$ was supplied as $\mathrm{Cu}(\mathrm{OH})_{2}$, addition of His, Met, Asp and casein increased $\mathrm{Cu}$ uptake by $2.86-8.85,3.81-6.19,3.81-12.39$ and 9.52$15.04 \%$ respectively. The corresponding values for $\mathrm{CuSO}_{4}$ with the addition of His, Met, Asp and casein were $10.88-14.60,4.08-4.32,3.24-6.80$ and $20.41-21.08 \%$ respectively. These results suggest that the addition of amino acids or casein to $\mathrm{Cu}$ fertilisers can increase chicory $\mathrm{Cu}$ uptake, but the agronomic value of the mixtures needs further investigation.
\end{abstract}

Keywords: additives, amino acids, casein, chicory (Cichorium intybus L), copper fertilisers, copper uptake

Abbreviations: Asp, aspartic acid; Glu, glutamic acid; His, histidine; Met, methionine; Gly, glycine; NA, nicotianamine; DW, dry weight.

\section{Introduction}

Copper deficiency in grazing animals is widespread in New Zealand, costing the farming industry several million dollars in animal remedies each year. In New Zealand, $\mathrm{Cu}$ deficiency in ruminants can occur as a result of ingesting pasture containing less than 3 to $4 \mathrm{mg} \mathrm{Cu} / \mathrm{kg} \mathrm{DM}$ and from molybdenum/sulphur induced $\mathrm{Cu}$ deficiency (Grace 1983). Recently, Grace et al. (1998) found a good correlation between herbage $\mathrm{Cu}$ concentration and liver $\mathrm{Cu}$ concentration of grazing Romney sheep. Only trace amounts of $\mathrm{Cu}$ are required for plants and animals, but the contents of forage plants may sometimes not provide adequate $\mathrm{Cu}$ intake for the optimum performance of ruminant animals (Jarvis 1978). Overcoming the problem with $\mathrm{Cu}$ fertilisers has met with mixed success, with generally low uptake of $\mathrm{Cu}$ by pasture plants. Low $\mathrm{Cu}$ uptake is caused by low solubility of plant-available forms of $\mathrm{Cu}$ in the soil solution and inefficient transport of $\mathrm{Cu}$ from roots to shoots (Jarvis 1978, 1980). An important contribution to the prevention of $\mathrm{Cu}$ deficiency in animals would be an effort to increase the $\mathrm{Cu}$ concentrations of forage plants. This can be achieved by modest increases in $\mathrm{Cu}$ uptake by major pasture grasses or by changing the botanical composition of the forage crop to include species with greater $\mathrm{Cu}$ content.

From the results of mathematical models, field experiments and studies with synthetic chelates, Bineev et al. (1985) confirmed that free amino acids in soils form chelates with $\mathrm{Cu}$ and thereby facilitate the migration of the trace element in the soil-plant system. More recently, it was found that free nicotianamine (NA) and histidine (His) are the major $\mathrm{Cu}$ transporters in tomato and chicory xylem sap (Liao et al. 1999; Pich \& Scholz 1996). Chicory (Cichorium intybus L), a forage plant, is recognised as having higher $\mathrm{Cu}$ concentration in shoots than many pasture species, and is a valuable source of forage $\mathrm{Cu}$ (Thomas et al. 1952). This paper tests the hypothesis that $\mathrm{Cu}$ uptake in chicory can be increased by addition of amino acids to $\mathrm{Cu}$ fertilisers, either by increasing water-soluble $\mathrm{Cu}$ in soils or $\mathrm{Cu}$ transport from roots to shoots.

\section{Materials and methods}

A sample of Manawatu silt loam $(2.9 \% \mathrm{OM}, 6.0 \mathrm{pH}$, $52 \mu \mathrm{g} / \mathrm{g}$ Olsen P, $17 \mathrm{meq} / 100 \mathrm{~g}$ soil CEC, $2 \mu \mathrm{g} / \mathrm{g}$ EDTA extractable $\mathrm{Cu}$ ) was obtained from a $0-15 \mathrm{~cm}$ soil depth under permanent pasture. The soil was air dried and sieved ( $<5 \mathrm{~mm}$ particle size). Sub-samples of $500 \mathrm{~g}$ soil were weighed into plastic bags. $\mathrm{Cu}$ was 
applied either as $\mathrm{Cu}(\mathrm{OH})_{2}$ or $\mathrm{CuSO}_{4}$ at $50 \mathrm{mg}$ or $100 \mathrm{mg}$ $\mathrm{Cu} / \mathrm{kg}$ air-dry soil. His, methionine (Met), aspartic acid (Asp) and casein were used as additives. The amount of amino acids (His, Met, Asp) and casein applied were determined by the amount needed to supply $18 \mathrm{mg}$ organic-N/pot. $\left(\mathrm{NH}_{4}\right)_{2} \mathrm{SO}_{4}$ was supplied to make up the total $\mathrm{N}$ application to $50 \mathrm{mg} /$ pot. The $\mathrm{Cu}$ fertilisers, amino acids, casein, and $\left(\mathrm{NH}_{4}\right)_{2} \mathrm{SO}_{4}$ were mixed with the dry soil in the plastic bags before placing the soil in the pots.

Even-sized chicory cv. Grassland Puna seedlings were transplanted into the pots. Distilled water was supplied to maintain $80 \%$ of pot water capacity. After 10 days, $200 \mathrm{ml}$ of $\mathrm{Cu}$-free complete nutrient solution was added weekly to each pot to supply $40 \mathrm{mg} \mathrm{N}$ for plant growth. Plants were harvested at 40, 70 and 90 days after transplanting. Harvested plant materials were rinsed with distilled water, and oven dried at $65^{\circ} \mathrm{C}$ for 48 hours. Plant dry weight (DW) was recorded. $\mathrm{Cu}$ concentrations in plant shoots were measured using flame atomic absorption spectrometry (FAAS) after digesting with $69 \%$ $\mathrm{HNO}_{3}$.

The significance of differences between treatment mean plant dry weights and $\mathrm{Cu}$ uptakes was tested using analysis of variance (ANOVA) (SAS Institute, Inc. 1987), and means were separated by LSD.

\section{Results and discussion}

Irrespective of the forms and rates of $\mathrm{Cu}$ applied, the addition of amino acids and casein had no significant effects on chicory shoot dry weight (data not shown). Over three harvests, the chicory shoot $\mathrm{Cu}$ concentrations ranged from 9 to $29 \mathrm{mg} \mathrm{Cu} / \mathrm{kg} \mathrm{DW}$ (Figure 1). No obvious $\mathrm{Cu}$ toxicity symptoms were observed in any of the treatments during the experimental period. No $\mathrm{Cu}$ deficiency symptoms were observed for the control plants grown in Manawatu silt loam.

Shoot $\mathrm{Cu}$ accumulation significantly increased (P values in Table 1) with increased application of $\mathrm{Cu}$ (Table 1). This result agrees with that of other workers (Beck 1962; Grace et al. 1998; Jarvis 1978, 1980). Applications of $\mathrm{CuSO}_{4}$ fertiliser resulted in significantly higher shoot $\mathrm{Cu}$ accumu- lation than $\mathrm{Cu}(\mathrm{OH})_{2}$ (Table 1), reflecting the lower solubility of $\mathrm{Cu}(\mathrm{OH})_{2}$.

When $\mathrm{Cu}$ was supplied as $\mathrm{Cu}(\mathrm{OH})_{2}$ at $50 \mathrm{mg} \mathrm{Cu} / \mathrm{kg}$ soil, there were no significant increases in shoot $\mathrm{Cu}$ concentration above the control pot (Figure 1). At 100 $\mathrm{mg} \mathrm{Cu} / \mathrm{kg}$ soil addition, $\mathrm{Cu}(\mathrm{OH})_{2}$ alone significantly increased shoot $\mathrm{Cu}$ concentration above the concentrations measured in the control pots. At harvest III, all amino acid and protein additives significantly increased shoot $\mathrm{Cu}$ concentration compared to control plant and $\mathrm{Cu}(\mathrm{OH})_{2}$ alone (Figure 1), but there were no significant differences among additives. This result is also reflected in the $\mathrm{Cu}$ uptake values reported in Table 2.

Application of $\mathrm{CuSO}_{4}$ significantly increased shoot $\mathrm{Cu}$ concentration compared to control plants. The casein $+\mathrm{CuSO}_{4}$ treatment resulted in significantly higher shoot $\mathrm{Cu}$ concentration than the treatment without additive $\left(\mathrm{CuSO}_{4}\right.$ alone) at harvest III at $50 \mathrm{mg} \mathrm{Cu}$ addition and

Figure 1 The effect of $\mathrm{Cu}$ source and amount applied on shoot $\mathrm{Cu}$ concentration of chicory plants grown in pots of Manawatu silt loam. A: $50 \mathrm{mg} \mathrm{Cu}$ as $\mathrm{Cu}(\mathrm{OH})_{2} / \mathrm{kg}$ soil; $\mathrm{B}: 100 \mathrm{mg}$ Cu as $\mathrm{Cu}(\mathrm{OH})_{2} / \mathrm{kg}$ soil; $\mathrm{C}: 50 \mathrm{mg}$ Cu as $\mathrm{CuSO}_{4} /$ $\mathrm{kg}$ soil; D: $100 \mathrm{mg} \mathrm{Cu}$ as $\mathrm{CuSO}_{4} / \mathrm{kg}$ soil. NS indicates no significant difference. The vertical bars are the $\mathrm{LSD}_{0.05}$ values calculated from ANOVA analysis. Significant differences $(P<0.05)$ between treatment means at a single harvest are signified by different letters.
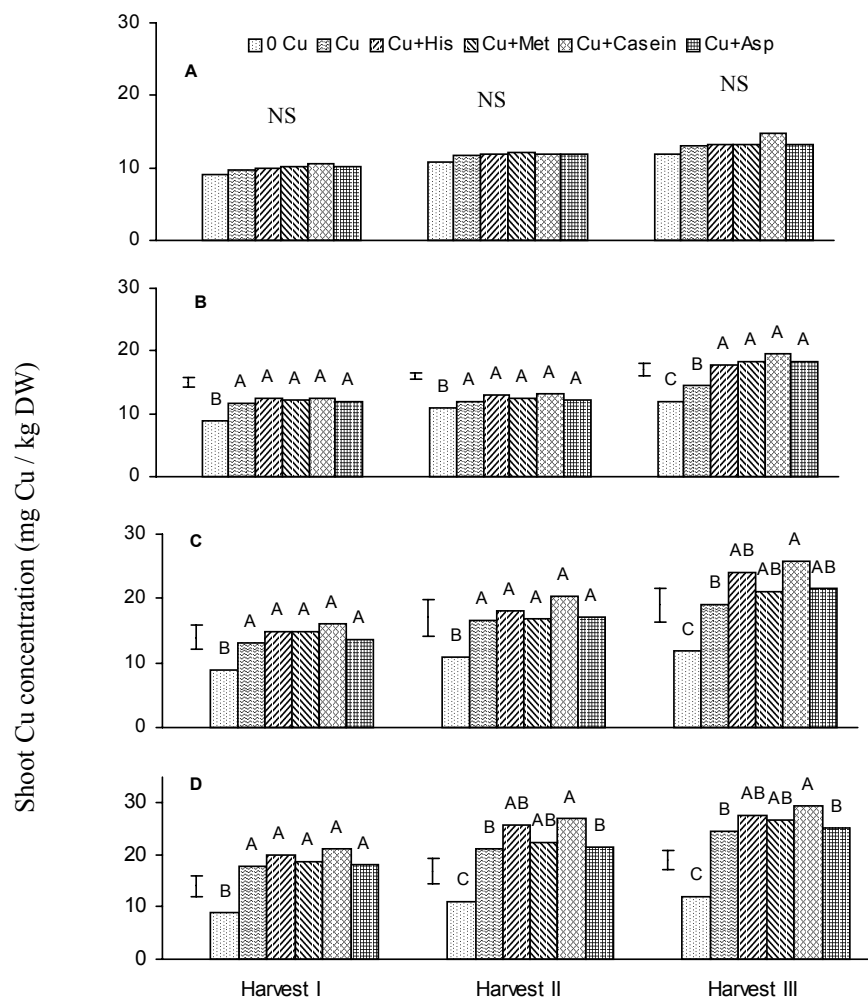
Table 1 Effects of Cu fertiliser source and amount applied on accumulated shoot dry weight, and shoot Cu accumulation of chicory plants. Data are means of three replicates.

\begin{tabular}{|c|c|c|c|c|c|}
\hline & \multicolumn{3}{|c|}{----- Shoot Cu uptake/pot (mg) - } & \multirow{2}{*}{$\begin{array}{c}\text { Total shoot dry weight/ } \\
\text { pot }(\mathrm{g})\end{array}$} & \multirow{2}{*}{$\begin{array}{c}\text { Total shoot } \mathrm{Cu} \text { uptake/ } \\
\text { pot }(\mathrm{mg})\end{array}$} \\
\hline & Harvest I & Harvest II & Harvest III & & \\
\hline \multicolumn{6}{|l|}{ Cu form } \\
\hline $\mathrm{Cu}(\mathrm{OH})_{2}$ & $0.041 \mathrm{a}$ & 0.039 a & $0.036 \mathrm{a}$ & 9.27 & $0.115 a$ \\
\hline $\mathrm{CuSO}_{4}$ & $0.065 b$ & $0.063 \mathrm{~b}$ & $0.053 \mathrm{~b}$ & 9.07 & $0.181 \mathrm{~b}$ \\
\hline $\mathrm{SE}^{1}$ & 0.003 & 0.002 & 0.002 & 0.16 & 0.003 \\
\hline$P$ & 0.05 & 0.01 & 0.05 & NS & 0.01 \\
\hline \multicolumn{6}{|c|}{$\begin{array}{l}\text { Cu level } \\
\text { (mg/kg soil) }\end{array}$} \\
\hline 0 & $0.035 a$ & $0.040 \mathrm{a}$ & $0.026 a$ & 9.47 & $0.102 \mathrm{a}$ \\
\hline 50 & $0.049 b$ & $0.045 \mathrm{a}$ & $0.039 \mathrm{~b}$ & 9.32 & $0.132 \mathrm{~b}$ \\
\hline 100 & $0.054 \mathrm{c}$ & $0.056 \mathrm{~b}$ & $0.048 \mathrm{c}$ & 9.03 & $0.158 \mathrm{c}$ \\
\hline $\mathrm{SE}^{1}$ & 0.003 & 0.003 & 0.002 & 0.34 & 0.005 \\
\hline$P$ & 0.01 & 0.05 & 0.01 & NS & 0.01 \\
\hline
\end{tabular}

Pool data are analysed.

${ }^{1} \mathrm{SE}:$ Standard error of mean.

Within a harvest, results of LSD tests are indicated either as not significant (NS) or at the probability level (P) stated, if significant.

Table 2 The effect of Cu source, amount applied and additives on accumulated biomass and accumulated Cu uptake. Data shown are means of three replicates. Results of LSD tests are indicated either as not significant (NS), or significantly different when means are labeled with different letters.

\begin{tabular}{|c|c|c|c|c|}
\hline Cu source & additive & $\begin{array}{l}\text { Accumulated biomass } \\
\text { (g) }\end{array}$ & $\begin{array}{l}\text { Accumulated Cu uptake } \\
\qquad(\mathrm{mg})\end{array}$ & $\begin{array}{l}\text { Efficiency of additive } \\
(\%)\end{array}$ \\
\hline $50 \mathrm{mg} \mathrm{Cu}$ as $\mathrm{Cu}(\mathrm{OH})_{2} / \mathrm{kg}$ soil & $\begin{array}{c}\mathrm{NL}^{1} \\
\mathrm{His} \\
\mathrm{Met} \\
\text { Asp } \\
\text { Casein } \\
\mathrm{P}\end{array}$ & $\begin{array}{l}9.46 \\
9.41 \\
9.45 \\
9.44 \\
9.58 \\
\text { NS }\end{array}$ & $\begin{array}{c}0.105 \\
0.108 \\
0.109 \\
0.109 \\
0.115 \\
\text { NS }\end{array}$ & $\begin{array}{l}2.86 \\
3.81 \\
3.81 \\
9.52\end{array}$ \\
\hline $100 \mathrm{mg} \mathrm{Cu}$ as $\mathrm{Cu}(\mathrm{OH})_{2} / \mathrm{kg}$ soil & $\begin{array}{c}\mathrm{NL} \\
\mathrm{His} \\
\mathrm{Met} \\
\text { Asp } \\
\text { Casein } \\
\mathrm{P}\end{array}$ & $\begin{array}{l}9.11 \\
9.12 \\
8.92 \\
9.28 \\
8.99 \\
\text { NS }\end{array}$ & $\begin{array}{c}0.113 \mathrm{a} \\
0.123 \mathrm{~b} \\
0.120 \mathrm{~b} \\
0.127 \mathrm{~b} \\
0.130 \mathrm{~b} \\
0.05\end{array}$ & $\begin{array}{r}8.85 \\
6.19 \\
12.39 \\
15.04\end{array}$ \\
\hline $50 \mathrm{mg} \mathrm{Cu}$ as $\mathrm{CuSO}_{4} / \mathrm{kg}$ soil & $\begin{array}{c}\mathrm{NL} \\
\mathrm{His} \\
\mathrm{Met} \\
\text { Asp } \\
\text { Casein } \\
\mathrm{P}\end{array}$ & $\begin{array}{l}9.25 \\
9.13 \\
9.08 \\
9.34 \\
9.06 \\
\text { NS }\end{array}$ & $\begin{array}{c}0.147 \mathrm{a} \\
0.163 \mathrm{ab} \\
0.153 \mathrm{a} \\
0.157 \mathrm{ab} \\
0.177 \mathrm{~b} \\
0.05\end{array}$ & $\begin{array}{r}10.88 \\
4.08 \\
6.80 \\
20.41\end{array}$ \\
\hline $100 \mathrm{mg} \mathrm{Cu}$ as $\mathrm{CuSO}_{4} / \mathrm{kg}$ soil & $\begin{array}{c}\mathrm{NL} \\
\mathrm{His} \\
\mathrm{Met} \\
\text { Asp } \\
\text { Casein } \\
\mathrm{P}\end{array}$ & $\begin{array}{l}9.00 \\
8.88 \\
8.83 \\
9.13 \\
8.91 \\
\text { NS }\end{array}$ & $\begin{array}{c}0.185 \mathrm{a} \\
0.212 \mathrm{~b} \\
0.193 \mathrm{a} \\
0.191 \mathrm{a} \\
0.224 \mathrm{c} \\
0.01\end{array}$ & $\begin{array}{r}14.60 \\
4.32 \\
3.24 \\
21.08\end{array}$ \\
\hline
\end{tabular}

${ }^{1} \mathrm{NL}$ : no additive

at harvest II and harvest III at $100 \mathrm{mg} \mathrm{Cu}$ addition (Figure 1). Total $\mathrm{Cu}$ uptake from casein $+\mathrm{Cu}$ was significantly higher than from Met $+\mathrm{Cu}$ and $\mathrm{CuSO}_{4}$ alone (Table 2). At the rate of $100 \mathrm{mg} \mathrm{Cu} / \mathrm{kg}$ soil as $\mathrm{CuSO}_{4}$, the addition of His and casein resulted in significantly higher total shoot $\mathrm{Cu}$ accumulation than Met, Asp and $\mathrm{CuSO}_{4}$ alone. The total shoot $\mathrm{Cu}$ accumulation of the casein $+\mathrm{Cu}$ treatment was significantly higher than the $\mathrm{His}+\mathrm{Cu}$ treatment (Table 2).

The effect of additives on chicory $\mathrm{Cu}$ uptake, expressed as efficiency of additives ( $(\mathrm{Cu}$ uptake with additives $-\mathrm{Cu}$ uptake without additives)/Cu uptake without additive $\times 100$ ) is presented in Table 2 . When 
$\mathrm{Cu}$ was supplied at $50 \mathrm{mg} \mathrm{Cu}$ as $\mathrm{Cu}(\mathrm{OH})_{2}$, addition of His, Met, Asp and casein increased $\mathrm{Cu}$ uptake by 2.86 , $3.81,3.81$ and $9.52 \%$ respectively. The corresponding values for $50 \mathrm{mg} \mathrm{Cu}$ as $\mathrm{CuSO}_{4}$ with addition of His, Met, Asp and casein were 10.88, 4.08, 6.80 and 20.41\% respectively. When $\mathrm{Cu}$ was supplied at $100 \mathrm{mg} \mathrm{Cu}$ as $\mathrm{Cu}(\mathrm{OH})_{2}$, addition of His, Met, Asp and casein increased $\mathrm{Cu}$ uptake by $8.85,6.19,12.39$ and $15.04 \%$ respectively. The corresponding values for $100 \mathrm{mg} \mathrm{Cu}$ as $\mathrm{CuSO}_{4}$ with addition of His, Met, Asp and casein were $14.60,4.32,3.24$ and $21.08 \%$ respectively. Bineev et al. (1985) found a similar result for rye by applying Met and Gly to a gray forest soil. They found that the total content of amino acids in soil increased as a result of enhanced microbial activity. Free amino acids in soil form chelates with $\mathrm{Cu}$ which facilitate the migration of the trace element in the soil-plant system.

\section{Conclusions and implications}

Under glasshouse conditions, initial $\mathrm{Cu}$ uptake by chicory plants from soil is more rapid from $\mathrm{CuSO}_{4}$ than $\mathrm{Cu}(\mathrm{OH})_{2}$ fertiliser because of the solubility differences between the sources. The initial uptake of $\mathrm{Cu}$ from $\mathrm{CuSO}_{4}$ fertilised soil can be increased by $10-21 \%$ by addition of His and casein. Casein was generally more effective at increasing plant $\mathrm{Cu}$ uptake than His and other amino acids. The results indicate that the agronomic value of amino acid- or protein-based $\mathrm{Cu}$ fertiliser may warrant further investigation, particularly aspects of granular fertiliser development and their $\mathrm{Cu}$ release rates.

\section{REFERENCES}

Beck, A.B. 1962. The levels of copper, molybdenum and inorganic sulphate in some Western Australian pastures. Australian journal of experimental agriculture, animal and husbandry 2: 40-45.
Bineev, R.G.; Grigor'yan, B.R.; Yul'met'ev, R.M.; Kazakov, K.S. 1985. Effects of amino acids on the absorption of copper from the soil by plants. Biologicheskie nauki 8: 81-85.

Grace, N.D. 1983. Copper $(\mathrm{Cu})$. In: The mineral requirements of grazing ruminants. Ed. Grace, N.D. New Zealand Society of Animal Production Occasional Publication No. 9: 57-66.

Grace, N.D.; Knowles, S.O.; Rounce, J.R.; West, D.M; Lee, J. 1998. Effect of increasing pasture copper concentrations on the copper status of grazing Romney sheep. New Zealand journal of agricultural research 41: 377-386.

Jarvis, S.C. 1978. Copper uptake and accumulation by perennial ryegrass grown in soil and solution culture. Journal of the science of food and agriculture 29: 12-18.

Jarvis, S.C. 1980. The uptake and distribution of copper in perennial ryegrass and white clover grown in flowing solution culture with a controlled supply of copper. Journal of the science of food and agriculture 31: 870-876.

Liao, M.T.; Hedley, M.J.; Woolley, D.J.; Brooks, R.R.; Nichols, M.A. 1999. Copper-induced amino acid synthesis in the xylem saps of tomato and chicory plants. Proceedings of the International Conference of Biogeochemistry of Trace Elements 5 (Accepted).

Pich, A.; Scholz, G. 1996. Translocation of copper and other micronutrients in tomato plants ( $\mathrm{Lyco} / \mathrm{sicon}$ esculentum Mill.): nicotianamine-stimulated copper transport in the xylem. Journal of experimental botany 47(294): 41-47.

SAS Institute, Inc. 1987. SAS user's guide: Statistics. Version 6.04. Cary, NC, SAS Institute, Inv.

Thomas, B.; Thompson, A.; Oyenuga, V.A.; Armstrong, R.H. 1952. The ash constituents of some herbage plants at different stages of maturity. Empire journal of experimental agriculture 20(77): 10-22. 